\title{
Are women more likely to throw the rascals out? The mobilizing effect of social service spending on female voters
}

\author{
Amy C. Alexander ${ }^{1} \cdot$ Andreas Bågenholm $^{1} \cdot$ Nicholas Charron $^{1}$
}

Received: 28 September 2019 / Accepted: 28 November 2019 / Published online: 12 December 2019

(c) The Author(s) 2019

\begin{abstract}
This study focuses on gender differences in voter reactions to a corruption scandal in one's preferred party. We analyze, in a framework of 'exit, voice and loyalty', whether women differ from men in terms of turnout (exit), and given that they vote, whether they prefer a clean alternative party (voice) or whether they continue to vote for their preferred party (loyalty) involved in a corruption scandal. We employ sequential logit models using data from the European Quality of Government Index (EQI) survey from 2017, which contains roughly 77,000 respondents from $21 \mathrm{EU}$ countries and 185 regions. We find that women generally are less tolerant of corruption, but that the effect is highly conditional. In areas where social service spending is more widespread, we find that female respondents are more likely to vote for an alternative party. Yet the odds of exit increase among women when social service spending is lower.
\end{abstract}

Keywords Corruption · Electoral accountability $\cdot$ Gender $\cdot$ Voting behavior $\cdot$ Welfare state $\cdot$ Female mobilization

\section{Introduction}

Electoral accountability, i.e., the extent to which voters vote retrospectively and reward or punish parties and politicians for their performances in office, is one of the cornerstones of the democratic polity. When accountability is lacking, politicians have little incentive to behave with integrity or strive to serve the public interest. Given the fact that most voters strongly dislike corruption and view the issue as a widespread, serious problem in their countries (Special Eurobarometer 2009, 2012, 2017), one would expect corrupt parties and politicians to be punished harshly on Election Day. Surprisingly, however, a growing body of literature on corruption voting reveals that the extent to which voters punish corrupt politicians is rather limited. Oftentimes, corrupt politicians even are reelected (Reed 1996; Chang et al. 2010; Barberá et al. 2012; Bågenholm 2013).

Despite a growing literature on gender and corruption, the role of gender is conspicuously absent from most of the literature on electoral responses to corruption. For example,

Amy C. Alexander

amy.alexander@gu.se

1 Department of Political Science, University of Gothenburg, Gothenburg, Sweden 
a recent review of the relevant literature does not mention the potential effects of gender (see de Vries and Solaz 2017). Yet, good reasons exist for believing that gender may have a significant impact on corruption voting. Indeed, since the early 2000 s, the research on corruption has revealed gender differences among masses and elites that have implications for various corruption outcomes. In mass-level research, public opinion and experimental studies show that women are less tolerant than men of corrupt behavior and less likely to engage in such behavior themselves (Chaudhuri 2012; Dollar et al. 2001; Swamy et al. 2001; Torlger and Valev 2010). On the elite level, scholars find that countries and regions with larger percentages of women in decision-making bodies tend to be less corrupt (Esarey and Schwindt-Bayer 2017; Jha and Sarangi 2018). Thus, broadly conceived, the research increasingly positions women as agents that are more likely to reduce corruption directly or indirectly.

A few recent studies have begun to incorporate gender into the corruption voting literature, reporting gender differences. Eggers et al. (2017) and Stensöta et al. (2015) find that female voters are more inclined to punish corrupt politicians and parties than are male voters. Stensöta et al. (2015) also find that women are less likely to vote for a corrupt political party if the country has a higher level of social spending, which is hypothesized to be associated with women's experiences of state services delivery that supports their selfdetermination and generates stronger provision of effective, clean service provision to them than to men.

The present study adds to that literature by applying a new theoretical approach to the study of gender and corruption voting, analyzing new data, a unique methodological approach and situating the findings in the larger body of work on corruption equilibria. We evaluate potential gender impacts on voter accountability by a novel theoretical application of the exit, voice and loyalty framework (Hirschman 1970; Bauhr and Charron 2018; Clark et al. 2017). We analyze whether women differ from men in exercising exit (abstaining from voting), or, if they vote, whether they differ from men in their tendencies to choose voice (vote for an alternative clean party) or loyalty (continue to vote for their preferred party which was involved in a corruption scandal). Guided by that framework, we are the first study to capture the role of gender across the range of sequential choices that confront voters when faced with corrupt politicians or parties. That approach allows us to pinpoint precisely how gendered accountability works, if it works at all—are women more likely than men to exercise exit or voice and, if so, in what context? Consequently, the approach taken herein also allows us to understand more precisely how the public service context in which women are embedded mobilizes their tendency to hold politicians or parties accountable more so than men.

We work with a new, larger cross-national dataset than previous studies, using survey data from the third round of the European Quality of Government Index (EQI) survey in 2017, which contains roughly 77,000 respondents from 185 regions in 21 EU countries. We also are the first to undertake an analysis of the impact of social service density on gender differences in voter accountability with data on sub-national units, thus gaining precision relative to national-level comparisons. Finally, our discussion of the results speculates on the broader implications of our findings for understanding virtuous and vicious cycles of corruption and generates a new theoretical framework to guide future research on female political mobilization, efforts to combat corruption and public service spending.

To estimate the gender effects we estimate multivariate, sequential logit models, a methodological approach that also is new to the literature. Our results show that while women are in fact more inclined to hold their preferred party accountable when it is involved in a corruption scandal, the relationship is more nuanced than previous research suggests. 
First, compared with men, women are slightly more likely to abstain from voting altogether (exit), but, given that they choose to vote, are much more likely to choose another clean party (voice) rather than remain loyal to the corrupt party they normally would have supported. Second, and in line with previous results, those effects are conditioned on our contextual factor - the amount of spending on and density of health and human services provision. Yet, new to the literature, we find that when spending and density in health and human services are low, they are associated with higher rates of abstention among women in the face of a corruption scandal in their otherwise preferred parties, but when those factors are sufficiently high, gender differences in exit disappear and the gender gap in voice versus loyalty widens significantly. Thus, women generally are less tolerant of corruption, but the gender difference is in regions where women have 'more to lose', i.e., where social service spending is greater and more dense female electoral accountability is more likely, relative to men, to be channeled through the voice alternative.

In our discussion of those results, we make an additional contribution to the literature by embedding the findings in the larger body of work on why countries and regions end up entrenched in good and bad equilibria of accountability, public service provision and corruption. Prior research on gender and corruption voting is silent on those larger implications for understanding corruption equilibria and what might punctuate or sustain them. We suggest a novel gendered interpretation that hinges on the role of public service provision in mobilizing women's aversion to corruption in the form of voice when high and exit when low.

In what follows, we review the literature on electoral accountability, gender and corruption, along with what little has been done on gender and corruption voting. The literature review is followed by our hypotheses, description of the data, description of methods, and presentation of the results. In the discussion of the results, we elaborate on the potential virtuous and vicious circles described above.

\section{Literature review, theory and hypotheses}

The research on corruption voting is quite unanimous in claiming that corrupt politicians get punished by the voters on Election Day, but to a surprisingly limited extent and oftentimes with the consequence that the offender still is reelected (Reed 1996; Chang et al. 2010; Barbera et al. Barberá 2012; Bågenholm 2013). The reasons why voters fail to 'throw the rascals out' are more contentious, with several competing explanations suggested (see de Sousa and Moriconi 2013; de Vries and Solaz 2017 for comprehensive overviews). First, voters simply may lack information about corruption scandals (Winters and WeitzShapiro 2013; see also Chang et al. 2010; Costas-Pérez et al. 2012) or distrust the information they get owing to a "home team effect" (de Sousa and Moriconi 2013). Second, even if the voters are well-informed and believe the information received, tradeoffs are to be made. For example, voters may prioritize factors other than corruption, such as the economy (see, e.g., Choi and Woo 2010; Casey 2014; Konstantinidis and Xezonakis 2013; Zechmeister and Zizumbo-Colunga 2013). Moreover, voters may benefit from some corrupt acts and as a result actively endorse the politicians that pursue them, for example, in the form of clientelism or other types of personal gains (Fernández-Vásquez et al. 2016; Manzetti and Wilson 2007). Third, some scholars focus on political institutions and how they affect the possibilities for voters to hold politicians accountable. Some scholars have argued that systems producing clarity of responsibility, such as majoritarian electoral systems that 
normally lead to one-party majority governments, facilitate electoral accountability (Persson et al. 2003; Kunikova and Rose-Ackerman 2005; Tavits 2007; Charron 2011). Others have stressed the importance of clean and reasonably close ideological alternatives, which tend to be more plentiful in PR systems (Charron and Bågenholm 2016).

Individual factors, such as gender, age and education have to a large extent been overlooked and rarely tested in their own right. Those factors are more typically entered as control variables. The limited findings so far are contradictory and inconclusive when it comes to age and education (de Sousa and Moriconi 2013), whereas the few studies of gender suggest that women are less tolerant of corrupt behavior (Stensöta et al. 2015; Eggers et al. 2017).

The largely unexplored role of gender in research on corruption and electoral accountability is rather surprising given the vast literature suggesting stark gender differences in the tendency to engage in, as well as the tolerance of, corruption (Alexander 2018; Alexander and Bågenholm 2018; Chaudhuri 2012; Dollar et al. 2001; Eggers, et al. 2017; Esarey and Chirillo 2013; Esarey and Schwindt-Bayer 2017; Jha and Sarangi 2018; Swamy et al. 2001; Sundström and Wängnerud 2014; Torlger and Valev 2010; Vijayalakshmi 2008; World Bank 2001). Within that literature, the work that speaks most strongly to expectations of gender differences in voter accountability offers theory and evidence on an "ethicality" mechanism to understand why women are likely to be more adverse to corruption than men (Cumming et al. 2015, pp. 1572-1573). Under that perspective, differences in gender role socialization emphasizing communalism and nurturing in the socialization of girls predispose women to be more sensitive to and concerned more about helping behavior, selflessness and regard for the welfare of others (Eagly et al. 2000). Such socialization increases the likelihood that women will behave more ethically, in the interest of the public good, than men. Several studies looking at a range of perceptions and behaviors related to ethical choices from corruption to tax evasion support a tendency among women, more so than among men, to hold ethical perceptions or behave ethically (Chaudhuri 2012; D'Attoma et al. 2017; Fišar et al. 2016; Rosenbaum et al. 2014; Swamy et al. 2001; Torlger and Valev 2010).

The decision regarding whether to continue to vote for one's preferred candidate or party if they are involved in corruption confronts an individual with a strong ethical dilemma and, yet, as we note above, the effect of gender largely is neglected in the corruption voting literature. Indeed, to our knowledge, only two studies have engaged directly with the question of corruption voting.

In an experimental study of British students, Eggers et al. (2017) find that women tend to punish corrupt representatives and candidates harsher than men do, but also-most interestingly - that female voters are harsher on female wrongdoers than on male wrongdoers. Those results suggest that women are indeed less tolerant towards corrupt behavior, but also that they hold female representatives to even higher standards.

In addition, Stensöta et al. (2015) find that women are less likely to support corrupt political parties, albeit with a key contextual qualification that our study engages with as well. The loss of women's support for corrupt political parties is particularly likely in countries that more effectively represent women's interests in the form of more extensive provision of social services. More specifically, Stensöta et al. find that across countries in Europe, women are less likely to vote for a corrupt political party if their country provides more generous social spending. According to that finding, Stensöta et al. conclude that the extent to which women are likely to combat corruption electorally may be conditional on the extent to which the state facilitates their self-determination by offering more employment opportunities and offsetting their care burdens. Such 
self-determination is facilitated by widespread, effective provision of social services. Under those experiences with the state, women acquire vested interests in the quality of public service provision and in seeing it free of corruption, because corruption has been found to have detrimental effects on publicly provided social services (see, for instance, Gupta and Tiongson 2000, p. 1). In a nutshell, Stensöta et al. suggest that the greater female tendency toward accountability is linked to how supportive the state is of women's self-determination in their everyday lives. Stensöta et al. emphasize that the welfare state provides both job opportunities and public services that facilitate female selfdetermination and that such policies create sources of motivation for women to react in ways protective of their interests, in the process punishing political elites who act destructively towards the state.

While Stensöta et al.'s study suggests that the welfare context widens gender gaps in tendencies to remain loyal in the face of corruption, with men showing more loyalty than women, the study fails to theorize and analyze whether women choose exit or voice as the alternative to loyalty in their greater tendencies to exercise their stronger desires for political accountability. The study also does not provide theory or analysis regarding how women's experiences with social service provision potentially influence the accountability mechanism for which they opt. We make our contribution to the literature by applying the accountability framework of exit, voice and loyalty to evaluate the relationship between gender, social service provision density and voter accountability. Guided by that framework, we are the first study to capture the role of gender across the range of sequential choices that confront voters when faced with corrupt politicians or parties. We conduct our more nuanced analysis by also including the non-vote option (exit), which we consider to be a milder form of accountability than voice. That approach allows us to pinpoint precisely how gendered accountability works, if it works at all-are women more likely to exercise exit or voice? We also can pinpoint more precisely how the public service context in which women are embedded mobilizes their tendency to hold politicians or parties accountable in comparison with men. That is an important advancement over the research published thus far. In the study by Stensöta et al. (2015), only gender differences in the loyalty option are analyzed; the exit and voice options are collapsed into a single reference category. By ignoring the sequence of choices voters potentially can make, it is unclear which form of accountability women are more likely to adopt; whether the level of public service provision mobilizes women differently across those categories of accountability compared to men likewise is an open question.

Thus, we begin with a figure that illustrates the exit, voice and loyalty options in order to theorize the role of gender in corruption voting and how that role might vary by differences in the level of public service provision. As illustrated by Fig. 1, voter responses to political corruption follow two key steps in a decision tree. In the first step, voters must decide whether to vote or not (exit). We elect to model that choice first, because the literature on the effect of corruption on voting behavior points to abstention as a primary consequence of corruption scandals (Chong et al. 2014; Sundström and Stockemer 2015; Dahlberg and Solevid 2016; Costas-Pérez 2013). Next, given that voters decide to vote, in the second step they must decide whether they will continue to vote for their preferred party regardless of the scandal (loyalty) or whether they will vote for a clean alternative (voice).

In terms of retrospective, political accountability, we posit a rank order in terms of responses. Loyalty clearly represents the option with the least amount of accountability, as the party or politician still gains the voters' support despite engaging in corruption. When it comes to exit, we view it as a form of accountability, because the corrupt party in question loses a vote from a previous supporter. Yet, voice is the strongest form of accountability, as 


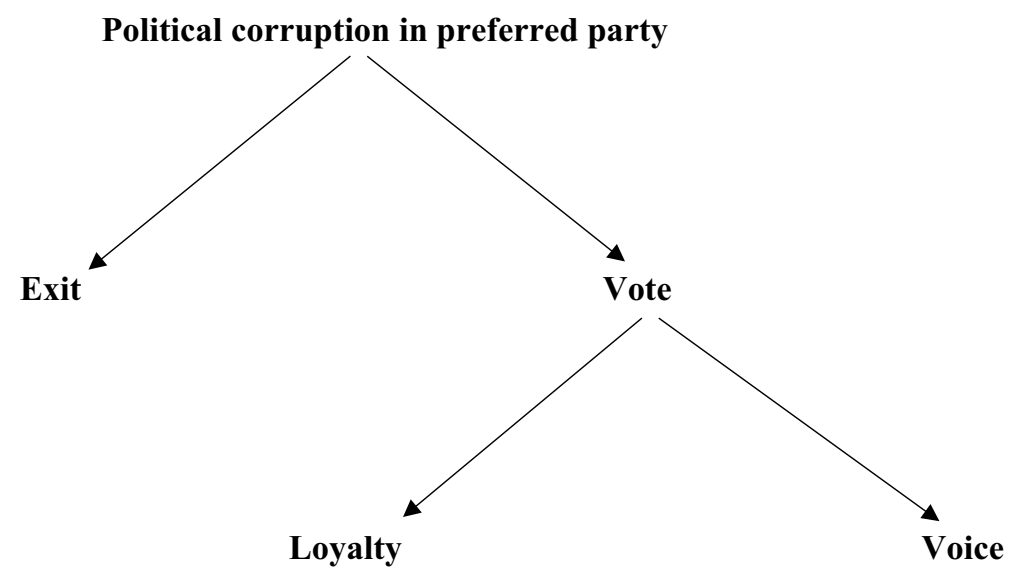

Fig. 1 Decision tree of voter response to political corruption

the corrupt party not only loses one vote, but a rival party also gains one, which makes the electoral punishment twice as effective.

Given the work on gender differences in ethicality, we theorize that women are less likely than men to reward corruption with loyalty and, conversely, that women are more likely to abstain from voting (exit) than men, or, if they vote, to opt for a clean alternative to a greater extent than men.

In addition, we theorize that, compared with male voters, the type of accountability women exercise in opposition to corruption hinges on the extent to which women have stakes in, or much to lose from, the delivery of public services. Here, we highlight the importance of public service provision for mobilizing women, which is contingent on the extent to which this provides both services and work that increase women's potential for self-determination and, therefore, commitment to a clean, effective state (Stensöta et al. 2015). More public service provision offsets the female relative to male care burden and expands the job opportunities that are most amenable to combining care and work responsibilities, generating state-driven gains in private and public autonomy for women. Thus, women stand to lose more if corrupt politicians are elected in regions or countries that spend more generously on health and welfare services and in areas where those sectors provide a relatively large share of the available employment opportunities. With more at stake, we expect that women are mobilized not only to behave ethically when faced with corruption, but to take action in their efforts to protect the public service environment that is instrumental to their self-determination. In that case, we expect that they will be especially likely to choose voice over loyalty by voting for an alternative than will men.

In line with the foregoing expectation, other research on gender voting gaps supplies evidence of the differential effect of the welfare state in mobilizing women versus men (Aidt and Dallal 2008; Iversen and Rosenbluth 2006; Lott and Kenny 1999). Particularly relevant to our study, Iversen and Rosenbluth (2006) find that women are mobilized to more strongly support the public sector by being more likely to vote for the left when they are in stronger welfare state contexts. In explaining why the welfare state mobilizes women more effectively, they find that in those contexts, marital exit and reducing their share of family work become real possibilities for women owing to expanded labor market opportunities for women and the provision of state services that offset the burden of family work 
that would fall disproportionately on women otherwise. Those events, in turn, give more bargaining power to women relative to men within the household regarding unpaid work and incentivize their support for the public sector.

To summarize, we make a novel theoretical argument positing that female demands for accountability in the face of political corruption represents a tradeoff between exit and voice, whereby the tradeoff is contingent on the extent of spending on and the density of welfare services. Faced with political corruption in one's party, we expect women to be more likely to exercise voice when they reside in areas with stronger social service sectors on which they depend for offsetting their care burdens and employment opportunities in their everyday lives; women have more to lose than men from corruption in such contexts, on average. Conversely, in areas where the size of the health and human welfare sector is small and women consequently are less dependent on such services and employment opportunities, exit becomes a more likely option. While corruption remains less tolerable among women than among men, ceteris paribus, incentives to take action by switching parties are weaker, since politics overall fails to work for women's interests. Thus, abstaining becomes a more likely way to react ethically against corruption. Consequently, as the importance of the welfare sector increases, loyalty becomes less salient as larger proportions of women turn out to vote and, when voting, they tend to choose voice in the face of corruption. One can assess the mobilization implication only by the more nuanced analysis of the decision tree that we conduct in this study. In line with the discussion above we hypothesize that:

H1 Female voters are more likely to hold their preferred political party accountable for a corruption scandal than male voters:

(a) Women are more likely to abstain (exit) than men.

(b) When voting, women are more likely to switch to a clean alternative (voice) than men.

H2 The way in which women express desires for accountability is contingent on the density of social service provision:

(a) The gender gap in terms of voice is wider in regions where the density of social service provisions is high and smaller where it is low.

(b) The gender gap in terms of exit is wider in regions where the density of social service provisions is low and smaller where it is high.

\section{Design, data and estimation}

To test the hypotheses elucidated in the previous section, we employ a comparative, observational design with data from the latest round of the European Quality of Government Index (EQI) survey (Charron et al. 2019). The survey includes approximately 77,000 individuals from $21 \mathrm{EU}$ Member States and was fielded during the summer of $2017 .{ }^{1}$

${ }^{1}$ More information about the survey is provided in the "Appendix". 
Employing a new, cross-national dataset that covers a larger number of European countries constitutes an empirical contribution to the literature.

On the dependent-variable side, we conceive of accountability using the exit, voice and loyalty framework (Hirschman 1970; Bauhr and Charron 2018; Clark et al. 2017). In our view of the main concept, we see voice as the choice that would result most effectively in holding a corrupt politician accountable, while exit is a more indirect and weaker way to punish the party. Loyalty, on the other hand, indicates corruption voting, i.e., the opposite of electoral accountability. To operationalize that concept, we take advantage of a question on corruption voting (Charron and Bågenholm 2016) from the 2017 round of the survey, whereby respondents were asked the following:

1. What political party would you vote for if the national parliamentary election were today?

2. Now imagine that that party was involved in a corruption scandal. Which of the following would be most likely? (a) Still vote for preferred party. (b) Vote for an alternative party not involved in the corruption scandal. (c) Not vote at all.

Prior to asking those questions, the term corruption was defined for the respondents in the following description: "In this survey we define corruption to mean 'the abuse of entrusted public power for private gain'”. We conceive of loyalty as choosing 'a' in (2) above, voice as choosing ' $b$ ', and exit as choosing ' $c$ '. ${ }^{2}$ In all, $13.1 \%$ of the respondents answered that they would still vote for the same party despite its involvement in corruption, while $48.2 \%$ responded that they would vote for another, clean party, and 35.5\% said that they would not vote at all. Three point two percent responded, 'don't know'. ${ }^{3}$

Our main independent variable is gender. We code female respondents 1 and men 0 . Other micro-level covariates that we enter into the analysis are education, which is 1 for university level education or higher, and 0 if otherwise. Age is entered as a four-point scale. We control for a respondent's employment status as 1 if unemployed and 0 if otherwise. In addition, we include a measure of political trust, which potentially could confound the relationship between gender and accountability. Trust is captured on a 0-10 scale, with higher values equating to higher levels of political trust.

At the macro level, we elect to measure at the sub-national (regional) as well as the country level in testing the cross-level interaction implied in $\mathrm{H} 2$. Here, the main variable of interest captures the extent to which one's area spends on welfare-type policies that are most likely to benefit women, on average. With no perfect comparative measure of 'universal welfare state' available, we elect to use the closest possible measures to best capture the concept in mind. At the regional level, we take employment in human health and social work activities as a percentage of total employment-public plus private. To test $\mathrm{H} 2$, we create an interaction between gender and those variables (in separate models), expecting

\footnotetext{
${ }^{2}$ We acknowledge some limitations to the measure of electoral accountability. Respondents are not asked to identify which alternative to which they would switch. In addition, the survey does not ask questions on the strength of attachment to the preferred party in question, such as how many years respondents have voted for that preferred party. Moreover, the survey does not include questions for varying the severity of the corruption in which the preferred party is involved. See also Charron and Bågenholm (2016) for more critical discussion of the variable.

3 We tested for gender differences in 'don't know' responses on the dependent variable and found the difference to be negligible $(p=0.52)$. We therefore drop the 'don't know' responses from the main analysis for purposes of drawing implications.
} 
that the gender gap for accountability, particularly the gap in selecting voice over loyalty, will be wider in areas where women have the most to lose and where they thereby are mobilized to defend their interests by voting for a clean alternative.

A preferable measure would be the proportion of spending in a region on health and human services as a proportion of its GDP, because the downside of our measure is that it is a relative and not an absolute one. For example, we might be overestimating the strength of the welfare state in economically weak regions with high unemployment, or underestimating it if the region's economy is diverse, but still spends more in absolute terms than the weaker one. Thus, we proceed with caution and attempt to control for factors that could be confounding the main relationship.

However, the sub-national measure is not without its advantages. For one, the provision of social services and opportunities to be employed by social services sectors vary significantly within countries. For example, employment in human health and social work activities as a percentage of a region's total employment within Italy is $60 \%$ larger in Trento $(10.5 \%)$ than it is Calabria (6.2\%). In France, the region of Limousin (17.4\%) has roughly a $70 \%$ larger share than the Île-de-France (10.2\%), and even in centralized Romania, the region of Bucharest (6.8\%) has approximately a $90 \%$ larger share on the same measure than Nord-Est (3.6\%). Given the intra-country variation in social service provision and employment opportunities, measuring those features at the sub-national level should approximate much more closely what women experience along them in their everyday lives. However, we check the relationship as well at the country level. Here, we follow Stensöta et al. (2015) and collect observations on a country's public health expenditures as percentages of GDP. The regional and country measures serve as proxies for social services programs from which women are likely to benefit and thus have more to lose when corruption takes place, because resources that might otherwise go to such services are siphoned off by corrupt elites.

We enter a parsimonious set of control variables at the macro level. First, we account for a region's (or country's) overall level of economic development in terms of GDP per capita (PPP) (from Eurostat), which we log for purposes of the analysis. Second, we control for the population density in a region (logged). Third, we account for the level of a polity's institutional quality, in terms of corruption, impartiality and quality of services with the EQI from 2013 (Charron et al. 2015), which captures a region's quality of governance temporally close to, yet prior to the outcome.

Finally, with no perfect way of capturing the extent to which gender roles are balanced (or imbalanced) in a given polity, we take the ratio of female unemployment to male unemployment (from Eurostat). We also check for the same (im)balance with a country-level proxy for the 2017 gender pay gap in hourly wages (from Eurostat). Finally, we control in some models for the proportionality of the electoral system by entering the average district magnitude from the World Bank's Database of Political Institutions. Table 1 reports summary statistics for the variables in the analysis.

\section{Results}

We begin by looking at the simple proportions of the three responses by gender. As shown in Fig. 2, the first sequence lends some initial support for the idea that women are more likely to react to a corruption scandal by being more likely (1.7 percentage points, on average) than men to choose exit, i.e., abstain from voting. In the second sequence, where the 
Table 1 Summary statistics

\begin{tabular}{|c|c|c|c|c|c|}
\hline Variable & Obs. & Mean & SD & Min & $\operatorname{Max}$ \\
\hline \multicolumn{6}{|l|}{ Individual level } \\
\hline Loyalty & 75,448 & 0.137 & 0.343 & 0 & 1 \\
\hline Voice & 75,448 & 0.494 & 0.500 & 0 & 1 \\
\hline Exit & 75,448 & 0.369 & 0.483 & 0 & 1 \\
\hline Female & 77,966 & 0.514 & 0.500 & 0 & 1 \\
\hline University & 77,966 & 0.423 & 0.494 & 0 & 1 \\
\hline Age 18-29 & 77,966 & 0.167 & 0.373 & 0 & 1 \\
\hline Age $30-44$ & 77,966 & 0.342 & 0.474 & 0 & 1 \\
\hline Age $45-59$ & 77,966 & 0.258 & 0.438 & 0 & 1 \\
\hline Age $60+$ & 77,966 & 0.232 & 0.422 & 0 & 1 \\
\hline Unemployed & 77,966 & 0.059 & 0.236 & 0 & 1 \\
\hline Political trust & 77,966 & 0.382 & 0.284 & 0 & 1 \\
\hline \multicolumn{6}{|l|}{ Regional level } \\
\hline Gender unemployment gap & 76,180 & 1.146 & 0.292 & 0.592 & 2.130 \\
\hline GDP p.c. (PPP, log) & 76,580 & 9.932 & 0.435 & 8.711 & 11.769 \\
\hline$\%$ Employment health, soc. services & 76,169 & 9.979 & 3.988 & 2.850 & 20.314 \\
\hline EQI & 75,208 & 0.149 & 0.963 & -2.473 & 2.137 \\
\hline \multicolumn{6}{|l|}{ Country level } \\
\hline GDP p.c. (PPP, log) & 77,966 & 10.463 & 0.272 & 9.765 & 10.845 \\
\hline Gender wage gap & 77,966 & 14.13 & 5.68 & 3.5 & 21.1 \\
\hline Average district magnitude & 77,966 & 12.23 & 22.37 & 1 & 150 \\
\hline Public health exp. & 77,966 & 7.006 & 1.740 & 4.474 & 10.025 \\
\hline
\end{tabular}

Unweighted means and standard deviations reported. All variables are re-scaled by min-max normalization $(0-1)$ for purposes of comparison with the main analyses

choice is between voice and loyalty (for those who chose to vote), we observe a larger gender gap (3.5 percentage points, on average).

In line with our expectations, women are more likely than men to switch to another clean party, whereas men consequently are more likely than women to remain loyal to their favorite party even if it is involved in a corruption scandal.

We move to test the hypotheses more systemically in Table 2. H1 states that a gender gap exists in accountability in terms of corruption voting. Our main method of estimation to account for the nested decision-making is by estimating a sequential logit model (Buis 2011), while multinomial logistic regressions are presented in the robustness checks. The estimation runs two simultaneous logit models, one in which the outcome is voting or not $(0 / 1)$, and another where one chooses voice or loyalty $(0 / 1)$; all estimates and standard errors in the sequential logit models are adjusted for the nested nature of the dependent variable. Hierarchical analysis with less than 30 cases at the highest level can result in inconsistent results (Stegmueller 2013); thus, we account for country-level differences with clustered standard errors by country. In the main models, we elect to present the macrolevel variables at the sub-national level, because degrees of freedom are larger with 185 regions than with 21 countries. The advantage of that approach is that we also capture important regional variation in the dependent variable as well as in the main macro-level variable-employment opportunities in the social and health service sectors. Moreover, the 


\section{Political corruption in preferred party}

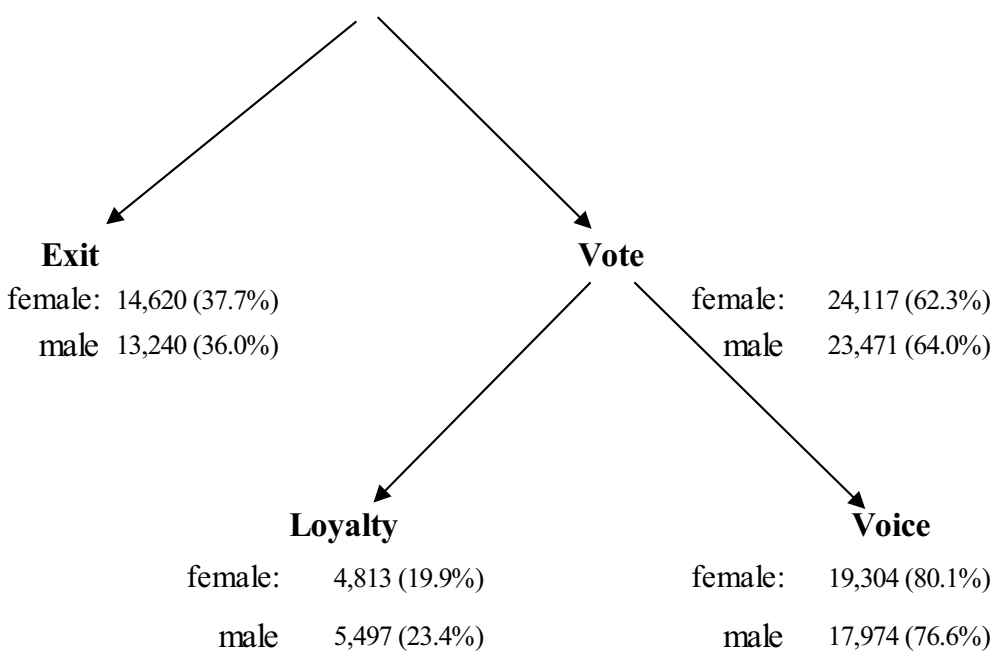

Fig. 2 Distribution of responses to political corruption by gender. Note The figure shows unweighted sample cross-tabulations of the dependent variable by gender (percentages by gender in parentheses). The first sequence, exit or vote, is based on the whole sample, while the second sequence, voice or loyalty, considers only those respondents who elected to vote

regional level provides more precision and the findings are less likely to be associated with possible confounding unmeasured items at the country level, such as unobserved cultural factors.

The effects of gendered accountability are noteworthy. On the one hand, as shown by the simple bivariate proportions in Fig. 2, we observe a significant increase in exit for female compared with male respondents. In Table 2, we include potentially confounding variables to our main relationship. For the sake of space, we present only our main variables, while the full set of results is reported in "Appendix" Table 4. All things being equal, Table 2, model 1 shows us that the odds of a female choosing exit in the face of a corruption scandal are 0.95 , or $5 \%$ higher than for a male, meaning that turnout is expected to be higher among men when one's preferred party is involved in corruption. However, the effects are relatively small in comparison with other covariates, such as unemployment or political trust.

We also find in accordance with our theoretical expectations that given that one chooses to vote, women are more inclined to exercise voice and far less likely to choose loyaltyimplying that women hold corrupt politicians to greater standards of accountability when showing up at the polls. The odds of a female choosing voice over loyalty, given that they do not exit, are 1.21 , or $21 \%$ higher, on average. ${ }^{4}$

Figure 3 elucidates the effect of the cross-level interaction (H2a and b) from model 2. We find that the results of the first choice between voting and abstaining in the sequence are strongest at the lower level of the moderating variable-health and social service density. Women in areas with lower spending on and density of health and human services

$\overline{4}$ Odds ratios are calculated in STATA, and are equal to $\exp (-0.069)=0.93$ and $\exp (0.196)=1.21$. 
Table 2 Sequential logit models

\begin{tabular}{lll}
\hline & Model 1: H1 & Model 2: H2 \\
\hline S1: exit (0) versus voting (1) & & \\
Female & $-0.069 * * *$ & $-0.120^{* * *}$ \\
& $(0.019)$ & $(0.035)$ \\
Health HS & -0.668 & -0.736 \\
& $(0.718)$ & $(0.708)$ \\
Female $*$ Health HS & & 0.131 \\
& & $(0.091)$ \\
Constant & $0.830 * *$ & $0.856 * *$ \\
S2: loyalty (0) versus voice (1) & $(0.339)$ & $(0.342)$ \\
Female & & \\
& $0.196 * * *$ & 0.068 \\
Health HS & $(0.030)$ & $(0.057)$ \\
Female*Health HS & $-1.033 * * *$ & $-1.181 * * *$ \\
Constant & $(0.300)$ & $(0.299)$ \\
Obs. & & $0.310 * * *$ \\
\hline
\end{tabular}

Estimates are logged odds from sequential logit models, with countryclustered standard errors in parentheses. Survey design and sample weights are used. Control variables include education, age, unemployment, political trust, the regional gender unemployment gap, GDP per capita (logged) and quality of regional institutions (EQI). Full results found in Table 4

$* * * p<0.01 ; * * p<0.05$

(i.e., where they have less to lose) are more likely simply to exit. As such, they show intolerance of corruption, but by abstaining from the voting process altogether. At minimum levels of the moderating variable, the probability of female exit increases by nearly $2 \%$ relative to males; the effect is significant until roughly the mean of the moderating variable is reached. Yet, the effect of gender on the choice to vote or exit is negligible beyond the mean of the moderating variable and virtually the same at its maximum level.

On the other hand, when respondents come from areas with more resources allocated to and higher density in health and human services provision, women are significantly more inclined to choose voice over loyalty, given that they vote in the first place. At maximum levels of the moderating variable, for example, the marginal effect of being female on the likelihood of choosing voice over loyalty is roughly $7.5 \%$ higher $(0.075)$ than being male. Given that women are roughly half of the electorate, that difference would result in roughly a 3.8\% vote swing away from the incumbent party involved in corruption.

That result implies that female accountability in response to corruption involves a tradeoff between exit and voice, and that the tradeoff is a direct function of the importance of the welfare state in terms of employment opportunities in the health and human services sector in the voter's area. We interpret that evidence as corroborating support for H2. Moreover, we observe in the second sequence of the model, that women's preferences for voice versus loyalty are related strongly to the share of social 

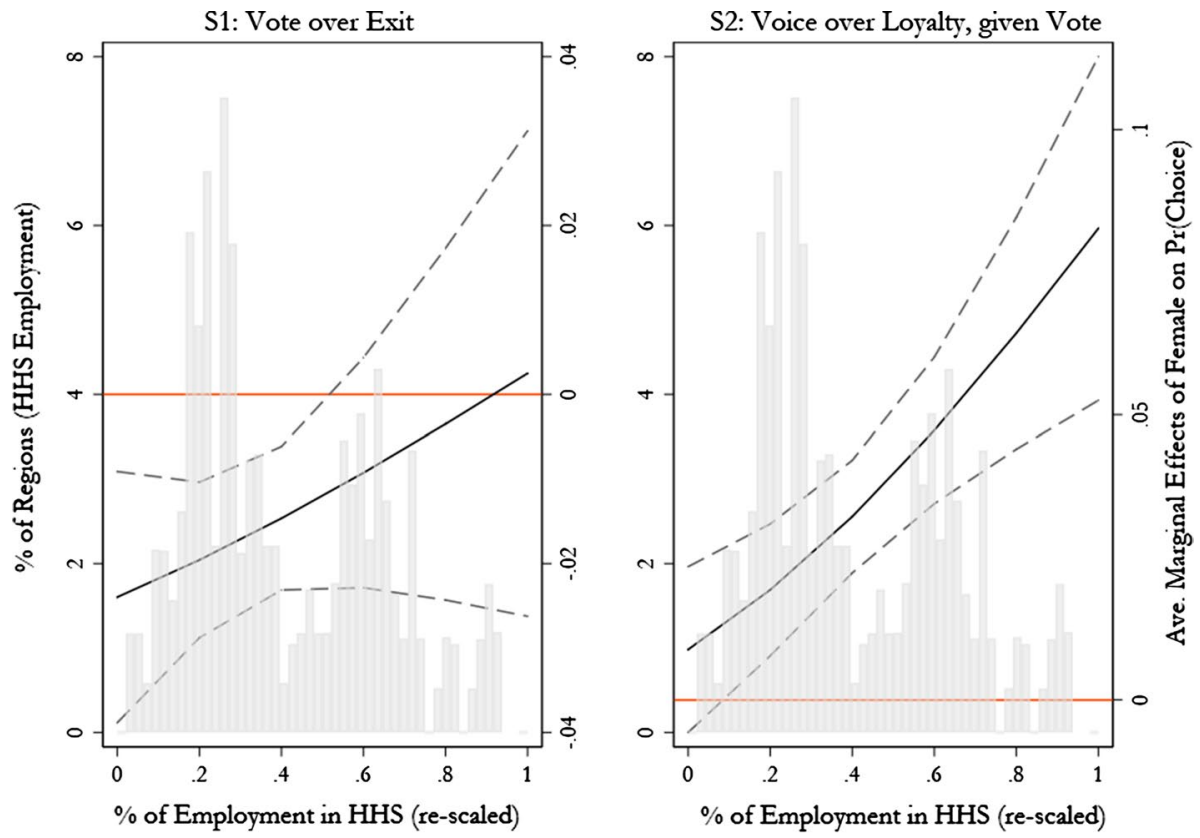

Fig. 3 Marginal effect of being female on vote choice. Note The figure depicts the average marginal effect of being female (compared with being a man) on electoral responses to corruption. S1 (left figure) shows the average marginal effect of being female on voting versus exit, whereas S2 (right side) shows the effect of being female on voice versus loylaty, given that one votes. The $\mathrm{x}$-axis shows the moderating variable, percentage employment in health and human services (HHS), minimums and maximums normalized between 0 and 1 . The figure includes a histogram of the distribution of the moderating variable. The lefthand side y-axis indicates the fraction of regions in the sample (e.g., regarding the histogram). The righthand side $y$-axis indicates the average marginal effect. A $95 \%$ confidence interval is shown, from country clustered standard errors

services employment. We observe that at very low levels, the model predicts no significant difference in those outcomes, given that one chooses to vote. However, in areas with larger shares of welfare service employment, the choice of voice rises dramatically relative to loyalty among women, demonstrating support for $\mathrm{H} 2 \mathrm{a}$.

As for the control variables, many of the estimates confirm previous findings in the literature. As for turnout at the individual level, political trust, and university education both are associated with an increased likelihood of voting, while unemployment and age $(60+)$ are correlated significantly with the choice of exit. As for the regional level covariates and turnout, the estimates show that areas with higher quality institutions have more voter turnout, on average, while areas with higher female-to-male unemployment gaps exhibit more exit, on average. The choice between voice and loyalty in the second sequence shows that age (60+) and political trust are associated with less voice and more loyalty. At the regional level, we see that only our moderating variable (HHS) has a significant effect on the choice between voice and loyalty, given that one votes in the first place. 


\section{Checking for alternative specifications}

We check the robustness of the findings in several ways. First, we re-run the estimates using a non-nested, multinomial logit model. Second, we enter country fixed effects into all estimations - sequential and multinomial. Third, we re-test $\mathrm{H} 2 \mathrm{a}$ and $\mathrm{H} 2 \mathrm{~b}$ using an interaction at the country level - the percentage of GDP spent on health. Fourth, we test an alternative contextual variable - the proportionality of the electoral system, proxied by average district magnitude. ${ }^{5}$ The results are reported in the "Appendix" (Tables 5, 6 and Fig. 6).

In sum, we find that the estimates using multinomial logit regression show effects substantively similar to those of the sequential logit estimates. Moreover, the interaction between gender and the health spending proxy at the country level (percentages of GDP on public health) shows strikingly similar results for $\mathrm{H} 2 \mathrm{a}$ and $\mathrm{H} 2 \mathrm{~b}$. We do not find any evidence, however, that the gender gap in corruption voting (H1) is conditioned significantly by district magnitude (see model 4, Table 6), nor does the addition of electoral system proportionality affect our main findings. Thus, the results of the alternative specifications are quite consistent with the previous findings in Table 2, providing evidence of the consistency of the regional-level measure.

\section{Discussion}

When faced with a corruption scandal in one's preferred party, the empirical tests show that women are more inclined toward holding their party accountable than men, on average. That finding, along with the moderating effect of the size of health and welfare spending constitutes a novel contribution to the corruption voting literature. However, we believe that our findings have broader implications than simply exploring the gender gap and explaining the conditions under which the gap appears when voters face corruption scandals involving their preferred parties. We maintain that our results also can give us a better understanding as to why countries and regions are entrenched in virtuous and vicious equilibriums, where strong (weak) public service provision reinforces high (poor) electoral accountability, which reinforces low (high) corruption. Our results suggest a role for gender in those two equilibriums, wherein higher (lower) public service provision mobilizes (demobilizes) women's aversive reaction to corruption in the form of voice (exit) (Fig. 4).

On the vicious side, the importance of the welfare state is minor and women thus have less interest in how the state is run. Since women tend to have lesser tolerance for corruption than men (owing to the ethicality mechanism), they still punish corrupt politicians, but primarily by not voting (exit). The female tendency to withdraw from the voting process enhances the importance of male voters, who tend to stay loyal to their preferred-and in this case corrupt - party. The likelihood of ousting corrupt incumbents thus declines, as does the likelihood of reducing the level of corruption. High levels of corruption, in turn, have a demonstrated detrimental effect on public services spending and thus on the extent and effectiveness of the welfare state (see, for instance, Gupta and Tiongson 2000).

On the virtuous side, the importance of the welfare state is elevated and women thus have more interest in how the state is run, which mobilizes political action on their part (voting) in the face of corruption. Hence, women's lesser tolerance of corruption than men

\footnotetext{
${ }^{5}$ We thank both reviewers at Public Choice for this suggestion.
} 


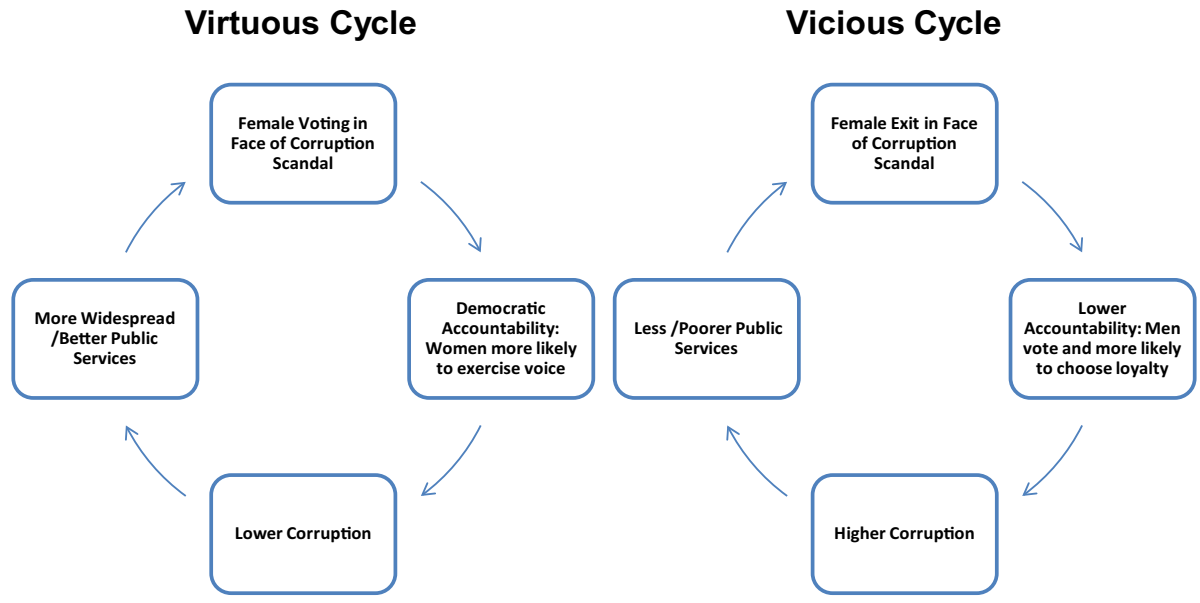

Fig. 4 The role of women in virtuous and vicious cycles, democratic accountability, public services and corruption

becomes mobilized in the form of voting for an alternative when faced with corruption in their preferred party (voice). A testable implication of that premise would be that among lower income respondents (those most dependent on public welfare services, on average) the gap between male and female preferences for voice would strengthen with the importance of the welfare state. We test a model with a triple interaction, including a dummy variable for low income multiplied by our main interaction. The results of that exercise show that, in fact, lower income women are predicted to choose voice relative to lower income men, but only when our moderating variable is relatively large (see "Appendix" Fig. 6 for a summary of the results). We do not find the gender effect when testing a threeway interaction with higher income respondents, however.

The greater likelihood for women to opt for voice plausibly increases democratic accountability and lowers corruption indirectly, rather than directly, such as by enacting stronger anti-corruption laws. The lower levels of corruption that likely ensue, in turn, strengthen public service provision and the importance of the welfare state for women.

Of the two posited cycles, perhaps our evidence speaks more strongly to the vicious cycle, particularly relating to assumptions about the link between electoral accountability and less corruption. Because it reasonably could be argued that weak electoral accountability, i.e., a tendency to remain loyal to corrupt politicians, results in sustained corruption, the opposite effect, that strong electoral accountability will reduce corruption, unfortunately is not as straightforward. Even when voters punish corrupt incumbents strongly, by voting for a clean alternative, the positive effects on corruption are all but certain, as research consistently has shown that corruption is difficult to fight even when the best intentions are at hand (see, for instance, Persson et al. 2013).

Under the virtuous and vicious cycle framework, our results contribute to the larger discussion as to why certain countries and regions have achieved more effective democratic accountability, better public services and less corruption. That we observe systematic differences in the ways in which women hold corrupt political parties accountable as 
a function of health and human services spending provides further support for the welfarestate institutional model of higher governmental quality (Rothstein 2001). Past studies have posited that universal welfare programs generate virtuous cycles in two ways. Universal welfare programs signal to citizens that the state allocates resources impartially, leading to more trust in government (Rothstein 2001; Kumlin and Rothstein 2005), generate better governance by reducing inequality, or both, which leads to higher levels of political and social trust (Rothstein and Uslaner 2005). Our study, however, highlights a previously overlooked additional mechanism through which the importance of welfare-state institutions improve democratic governance-namely by the mechanism of 'gendered accountability'. Accountability is best achieved when a sufficient number of citizens choose to exercise voice in the face of corruption. Yet, while women are less tolerant of corruption in general than men, the way in which they protest against it electorally varies from exit to voice as a function of the size and scope of the welfare state. We interpret our evidence as the following demonstrating. When welfare-state institutions are universal and wide-reaching, citizens - in particular women - recognize that they have 'something to lose' when politicians engage in corruption, as corruption siphons resources that otherwise would go to public welfare programs on which people rely, helping to contribute to the virtuous cycle of democratic accountability.

\section{Conclusion}

This study adds to the research on electoral responses to corruption, namely by addressing the conspicuous absence of gender from that literature. We offer a new conceptual framework so as understand more precisely the dynamics of the effect of gender on corruption voting. We evaluate the potential gender impact on voter accountability, i.e., voter reactions to a corruption scandal in one's preferred party, by using the exit, voice and loyalty framework (Hirschman 1970; Bauhr and Charron 2018; Clark et al. 2017). By incorporating the full sequence of choices voters potentially can make in response to a corruption scandal in their preferred party, we are able to determine the form of accountability women versus men are more likely to adopt, as well as whether the level of public service provision mobilizes women differently than men across the exit and voice categories of accountability.

Our results show that while women are in fact more inclined to hold their preferred party accountable when it is involved in a corruption scandal, the relationship is more nuanced than previous research suggests. First, compared with men, women are slightly more likely to abstain from voting altogether (exit), but given that they choose to vote, they are much more likely to choose another clean party (voice) rather than staying loyal to the corrupt party that they normally would support. Second, and in line with previous results, those effects are conditioned on and enhanced by our contextual factor-the amount of spending on and density of health and human services, which, when low, is associated with higher rates of abstention among women in the face of a corruption scandal in their otherwise preferred party. However, when spending on and density of health and human services are sufficiently high, gender differences in exit disappear and the gender gap in voice versus loyalty widens significantly. Thus, women generally are less tolerant of corruption, but that intolerance materializes in regions where women have more to lose. Where social service 
spending is higher and such services are more widespread, female electoral accountability is more likely, relative to men, to be channeled through the voice alternative.

The results reported herein strongly support the state as a facilitator of women's selfdetermination as the mechanism behind the link between gender and the strongest form of voter accountability in the face of corruption, voice. The theory argues that women's greater likelihood of opposing corruption as voters may be conditional on the extent to which the state supports their autonomy with policies that offset their care burden and generate opportunities for their employment. If the positive experiences women have along those lines truly mobilize them to hold corrupt politicians accountable, then we would expect women to be more likely to exercise voice when they encounter a more generous social service sector in their everyday lives. Our results are consistent with that mobilization implication.

We expand the research agenda for understanding low and high corruption equilibria by suggesting adding a gender piece to that puzzle, given the implications of our research for understanding virtuous or vicious cycles of accountability, public service provision and corruption. We introduce the gendered accountability mechanism to the existing line of research whereby higher (lower) public service provision mobilizes (demobilizes) women's aversive reactions to corruption in the form of voice (exit). Contributing to a virtuous cycle, we posit that when welfare-state institutions are universal and wide-reaching, women recognize that they have 'something to lose' when politicians engage in corruption, as corruption siphons resources that otherwise would go to public welfare programs on which they especially rely, helping to contribute to the virtuous cycle of democratic accountability.

Acknowledgements Open access funding provided by University of Gothenburg.

Open Access This article is licensed under a Creative Commons Attribution 4.0 International License, which permits use, sharing, adaptation, distribution and reproduction in any medium or format, as long as you give appropriate credit to the original author(s) and the source, provide a link to the Creative Commons licence, and indicate if changes were made. The images or other third party material in this article are included in the article's Creative Commons licence, unless indicated otherwise in a credit line to the material. If material is not included in the article's Creative Commons licence and your intended use is not permitted by statutory regulation or exceeds the permitted use, you will need to obtain permission directly from the copyright holder. To view a copy of this licence, visit http://creativecommons.org/licenses/by/4.0/.

\section{Appendix: background on survey}

The field work began during the month of May, 2017 and were conducted in the local majority language in each country/region. The results were returned to the Quality of Government Institute in August, 2017.

The E.U. regional survey was undertaken by Efficience 3 (E3), a French marketresearch, Survey Company specializing in public opinion throughout Europe for researchers, politicians and advertising firms. E3 has also conducted the 2010 and 2013 rounds of the EQI and were thus familiar with the question format and goals of the survey. E3 conducted the interviews themselves in several countries and used sub-contracting partners in others. ${ }^{6}$ The respondents, from 18 years of age or older, were contacted randomly via telephone in the local language. Telephone interviews were conducted via both landlines and

\footnotetext{
${ }^{6} \mathrm{http} / / / \mathrm{www}$. efficience3.com/en/accueil/index.html. For names of the specific firms to which Efficience 3 sub-contracted in individual countries, please write cati@efficience3.com.
} 
Table 3 Survey statistics by country

\begin{tabular}{|c|c|c|c|c|}
\hline Country & $\begin{array}{l}\text { Number of } \\
\text { respondents }\end{array}$ & $\begin{array}{l}\text { Sample per NUTS } \\
\text { region }\end{array}$ & $\%$ total sample & $\begin{array}{l}\text { Proportion } \\
\text { mobile respond- } \\
\text { ents }\end{array}$ \\
\hline Austria & 4050 & 450 & 5.2 & 0.521 \\
\hline Belgium & 1350 & 450 & 1.7 & 0.453 \\
\hline Bulgaria & 2400 & 400 & 3.1 & 0.796 \\
\hline Croatia & 900 & 450 & 1.2 & 0.482 \\
\hline Czech Rep. & 3600 & 450 & 4.6 & 1.000 \\
\hline Denmark & 2250 & 450 & 2.9 & 0.957 \\
\hline Finland & 2000 & 400 & 2.6 & 0.982 \\
\hline France & 10,422 & 401 & 13.4 & 0.647 \\
\hline Germany & 7200 & 450 & 9.2 & 0.237 \\
\hline Greece & 1620 & 405 & 2.1 & 0.519 \\
\hline Hungary & 2800 & 400 & 3.6 & 1.000 \\
\hline Ireland & 900 & 450 & 1.2 & 0.382 \\
\hline Italy & 8400 & 400 & 10.8 & 0.643 \\
\hline Netherlands & 1840 & 460 & 2.4 & 0.552 \\
\hline Poland & 6442 & 403 & 8.3 & 0.900 \\
\hline Portugal & 2800 & 400 & 3.6 & 0.745 \\
\hline Romania & 3600 & 450 & 4.6 & 0.611 \\
\hline Slovakia & 1800 & 450 & 2.3 & 1.000 \\
\hline Spain & 6992 & 411 & 9 & 0.641 \\
\hline Sweden & 1200 & 400 & 1.5 & 0.905 \\
\hline UK & 5400 & 450 & 6.9 & 0.244 \\
\hline
\end{tabular}

mobile phones, with both methods being used in most countries. Decisions about whether to contact residents more often via land or mobile lines was based on local expertise of market research firms in each country. For purposes of regional placement, respondents were asked the post code of their address to verify the area/region of residence if mobile phones were used (Tables 3, 4).

Ideally, a survey would be a mirror image of actual societal demographics-gender, income, education, rural-urban, ethnicity, etc. However, we are not privy to exact demographic distributions; in particular at the regional level in most cases, thus imposing artificial demographic lines might lead to even more problems than benefits. We thus sought the next best solution. Based on their expert advice, to achieve a random sample, we used what was known in survey-research as the 'next birthday method'. The next birthday method is an alternative to the so-called quotas method. When using the quota method for instance, one obtains a (near) perfectly representative sample-e.g. a near exact proportion of the amount of men, women, certain minority groups, people of a certain age, income, etc. However, as one searches for certain demographics within the population, one might end up with only 'available' respondents, or those that are more 'eager' to respond to surveys, which can lead to less variation in the responses, or even bias in the results. The 'next-birthday' method, which simply requires the interviewer to 
Table 4 Full results from Table 2

\begin{tabular}{|c|c|c|}
\hline & $\begin{array}{l}(1) \\
\text { H1 }\end{array}$ & $\begin{array}{l}(2) \\
\mathrm{H} 2\end{array}$ \\
\hline \multicolumn{3}{|c|}{ S1: exit (0) versus voting (1) } \\
\hline Female & $\begin{array}{l}-0.069 * * * \\
(0.019)\end{array}$ & $\begin{array}{l}-0.120^{* * * *} \\
(0.035)\end{array}$ \\
\hline Health HS & $\begin{array}{l}-0.668 \\
(0.718)\end{array}$ & $\begin{array}{l}-0.736 \\
(0.708)\end{array}$ \\
\hline Female*Health HS & & $\begin{array}{l}0.131 \\
(0.091)\end{array}$ \\
\hline University & $\begin{array}{l}0.385^{* * * *} \\
(0.059)\end{array}$ & $\begin{array}{l}0.385 * * * \\
(0.059)\end{array}$ \\
\hline Age $30-44$ & $\begin{array}{l}-0.040 \\
(0.038)\end{array}$ & $\begin{array}{l}-0.040 \\
(0.038)\end{array}$ \\
\hline Age $45-59$ & $\begin{array}{l}-0.055 \\
(0.037)\end{array}$ & $\begin{array}{l}-0.055 \\
(0.037)\end{array}$ \\
\hline Age $60+$ & $\begin{array}{l}-0.238^{* * *} \\
(0.056)\end{array}$ & $\begin{array}{l}-0.237 * * * \\
(0.056)\end{array}$ \\
\hline Unemployed & $\begin{array}{l}-0.355^{* * * *} \\
(0.071)\end{array}$ & $\begin{array}{l}-0.355^{* * * *} \\
(0.071)\end{array}$ \\
\hline Political trust & $\begin{array}{l}0.095 * * * \\
(0.015)\end{array}$ & $\begin{array}{l}0.095 * * * \\
(0.015)\end{array}$ \\
\hline Gender gap & $\begin{array}{l}-1.072 * * \\
(0.473)\end{array}$ & $\begin{array}{l}-1.072^{* *} \\
(0.473)\end{array}$ \\
\hline GDP pc $(\log )$ & $\begin{array}{l}-0.291 \\
(0.531)\end{array}$ & $\begin{array}{l}-0.291 \\
(0.531)\end{array}$ \\
\hline EQI & $\begin{array}{l}0.194 * \\
(0.106)\end{array}$ & $\begin{array}{l}0.194^{*} \\
(0.106)\end{array}$ \\
\hline Pop. density (log) & $\begin{array}{l}0.151 \\
(0.483)\end{array}$ & $\begin{array}{l}0.151 \\
(0.483)\end{array}$ \\
\hline Constant & $\begin{array}{l}0.830 * * \\
(0.339)\end{array}$ & $\begin{array}{l}0.856 * * \\
(0.342)\end{array}$ \\
\hline \multicolumn{3}{|c|}{ S2: loyalty (0) versus voice (1) } \\
\hline Female & $\begin{array}{l}0.196 * * * \\
(0.030)\end{array}$ & $\begin{array}{l}0.068 \\
(0.057)\end{array}$ \\
\hline Health HS & $\begin{array}{l}-1.033^{* * *} \\
(0.300)\end{array}$ & $\begin{array}{l}-1.181 * * * \\
(0.299)\end{array}$ \\
\hline Female ${ }^{*}$ Health HS & & $\begin{array}{l}0.310^{* * *} \\
(0.115)\end{array}$ \\
\hline University & $\begin{array}{l}0.059 \\
(0.073)\end{array}$ & $\begin{array}{l}0.059 \\
(0.074)\end{array}$ \\
\hline Age 30-44 & $\begin{array}{l}-0.021 \\
(0.055)\end{array}$ & $\begin{array}{l}-0.023 \\
(0.055)\end{array}$ \\
\hline Age $45-59$ & $\begin{array}{l}-0.142 \\
(0.095)\end{array}$ & $\begin{array}{l}-0.143 \\
(0.096)\end{array}$ \\
\hline Age $60+$ & $\begin{array}{l}-0.355^{* * * *} \\
(0.103)\end{array}$ & $\begin{array}{l}-0.355^{* * * *} \\
(0.103)\end{array}$ \\
\hline
\end{tabular}


Table 4 (continued)

\begin{tabular}{lll}
\hline & $(1)$ & $(2)$ \\
& H1 & H2 \\
\hline Unemployed & 0.081 & 0.082 \\
& $(0.090)$ & $(0.090)$ \\
Political trust & $-0.055^{* *}$ & $-0.055^{* *}$ \\
Gender gap & $(0.024)$ & $(0.024)$ \\
& -0.492 & -0.493 \\
GDP pc $(\log )$ & $(0.600)$ & $(0.599)$ \\
& $0.937 * *$ & $0.934 * *$ \\
EQI & $(0.463)$ & $(0.463)$ \\
Pop. density $(\log )$ & 0.140 & 0.139 \\
Constant & $(0.124)$ & $(0.123)$ \\
& -0.494 & -0.491 \\
Obs. & $(0.375)$ & $(0.376)$ \\
\hline
\end{tabular}

Full results from Table 2 in main text reported from sequential logit estimation. Logged odds with country-clustered standard errors are in parenthesis

$* * * p<0.01 ; * * p<0.05 ; * p<0.1$

ask the person who answers the phone who in their household will have the next birthday, still obtains a reasonably representative sample of the population. The interviewer must take the person who has the next coming birthday in the household (if this person is not available, the interviewer makes an appointment), thus not relying on whomever might simply be available to respond in the household. So, where the quota method is stronger in terms of a more even demographic spread in the sample, the next-birthday method is stronger at ensuring a better range of opinion. The next-birthday method was thus chosen because we felt that what we might have lost in demographic representation in the sample would be made up for by a better distribution of opinion. In attempt to compensate for some key demographic over/under-representation, E3 provides weights based on age and gender for each region, comparing the sample drawn to actual demographic statistics from Eurostat. In the end, we find variation in response and refusal rates by country, which could have to do with many factors including the sensitivity of one of the primary the topics at hand-corruption.

\section{Robustness checks: alternative specifications}

See Figs. 5 and 6, Tables 5 and 6. 

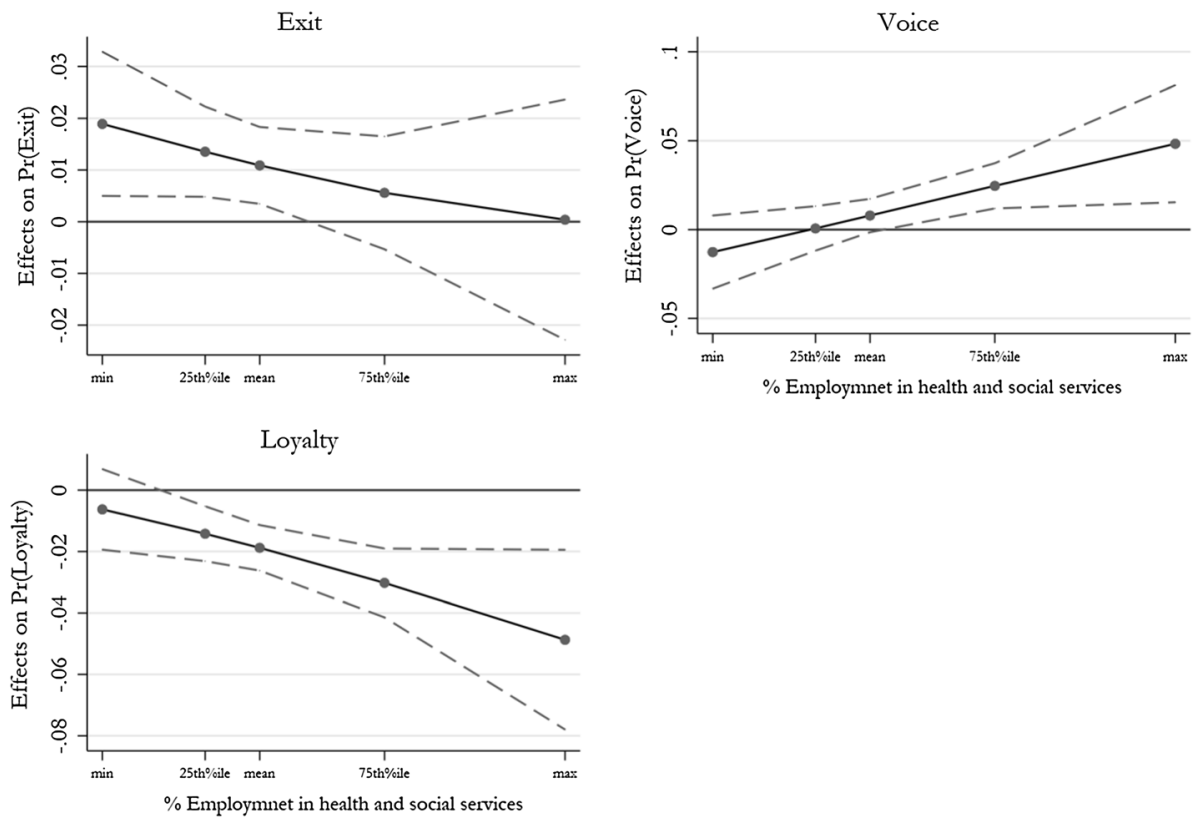

Fig. 5 Re-test of H2: cross-level interactions from multinomial logit. Note Marginal effects of female on the three outcomes with cross-level interaction model from multinomial logistic regression. Observations are weighted by design and sample weights. Values of 'min', 25\%ile, mean, 75\%ile and max represent the corresponding levels of the moderating variable, \% employment in health and human services

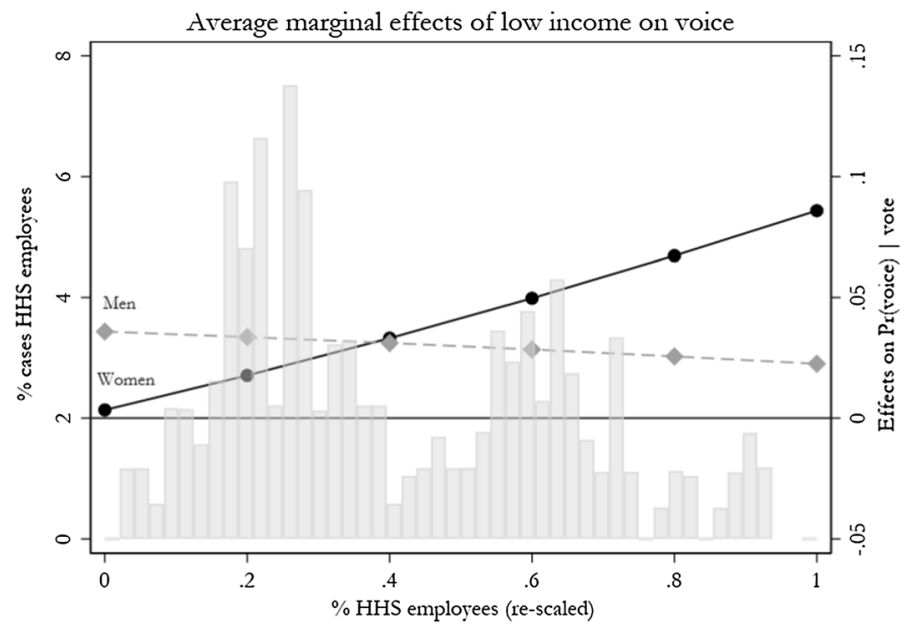

Fig. 6 Three-way interaction-HHS, gender and income. Note This figure shows the results of a 3-way interaction test between country level health expenditures, income (low) and gender. Predicted effects of the probability of voice (over loyalty, given no exit) are shown on the right-side y-axis. Effects of low income (compared with middle or high) among women are the black line while the income effects among men are the grey dashed line. Models include all individual and contextual level covariates as model 3, Table 2. Estimates account for survey sample and design weights and include country-clustered standard errors 
Table 5 Multinomial logic estimates (bassline group $=$ LOYALTY)

\begin{tabular}{|c|c|c|}
\hline & $\begin{array}{l}(2) \\
\text { Vote3 }\end{array}$ & $\begin{array}{l}(1) \\
\text { Vote3 }\end{array}$ \\
\hline \multicolumn{3}{|l|}{ VOICE } \\
\hline Female & $\begin{array}{l}0.204 * * * \\
(0.031)\end{array}$ & $\begin{array}{l}0.065 \\
(0.077)\end{array}$ \\
\hline HHS & $\begin{array}{l}-1.039 * * * \\
(0.326)\end{array}$ & $\begin{array}{l}-1.193 \text { *** } \\
(0.326)\end{array}$ \\
\hline Female * HHS & & $\begin{array}{l}0.313 * * \\
(0.158)\end{array}$ \\
\hline University & $\begin{array}{l}0.047 \\
(0.079)\end{array}$ & $\begin{array}{l}0.048 \\
(0.079)\end{array}$ \\
\hline Age $30-44$ & $\begin{array}{l}-0.003 \\
(0.054)\end{array}$ & $\begin{array}{l}-0.003 \\
(0.054)\end{array}$ \\
\hline Age $45-59$ & $\begin{array}{l}-0.088 \\
(0.089)\end{array}$ & $\begin{array}{l}-0.088 \\
(0.089)\end{array}$ \\
\hline Age $60+$ & $\begin{array}{l}-0.291 * * * \\
(0.095)\end{array}$ & $\begin{array}{l}-0.290 * * * \\
(0.095)\end{array}$ \\
\hline Unemployed & $\begin{array}{l}0.113 \\
(0.099)\end{array}$ & $\begin{array}{l}0.115 \\
(0.100)\end{array}$ \\
\hline Political trust & $\begin{array}{l}-0.043 * * \\
(0.019)\end{array}$ & $\begin{array}{l}-0.043^{* *} \\
(0.019)\end{array}$ \\
\hline HHS & $\begin{array}{l}-0.660 \\
(0.529)\end{array}$ & $\begin{array}{l}-0.660 \\
(0.529)\end{array}$ \\
\hline Gender gap unemployment & $\begin{array}{l}0.695 \\
(0.495)\end{array}$ & $\begin{array}{l}0.693 \\
(0.495)\end{array}$ \\
\hline GDP pc (log) & $\begin{array}{l}0.089 \\
(0.112)\end{array}$ & $\begin{array}{l}0.088 \\
(0.112)\end{array}$ \\
\hline EQI & $\begin{array}{l}-0.445 \\
(0.351)\end{array}$ & $\begin{array}{l}-0.443 \\
(0.352)\end{array}$ \\
\hline Constant & $\begin{array}{l}2.056^{* * *} \\
(0.452)\end{array}$ & $\begin{array}{l}2.123 * * * \\
(0.443)\end{array}$ \\
\hline \multicolumn{3}{|l|}{ EXIT } \\
\hline Female & $\begin{array}{l}0.216^{* * * *} \\
(0.034)\end{array}$ & $\begin{array}{l}0.167 * * * \\
(0.064)\end{array}$ \\
\hline HHS & $\begin{array}{l}0.075 \\
(0.535)\end{array}$ & $\begin{array}{l}0.033 \\
(0.554)\end{array}$ \\
\hline Female *HHS & & $\begin{array}{l}0.101 \\
(0.144)\end{array}$ \\
\hline University & $\begin{array}{l}-0.386^{* * *} \\
(0.048)\end{array}$ & $\begin{array}{l}-0.386^{* * * *} \\
(0.048)\end{array}$ \\
\hline Age 30-44 & $\begin{array}{l}0.026 \\
(0.060)\end{array}$ & $\begin{array}{l}0.025 \\
(0.061)\end{array}$ \\
\hline Age $45-59$ & $\begin{array}{l}-0.048 \\
(0.082)\end{array}$ & $\begin{array}{l}-0.048 \\
(0.082)\end{array}$ \\
\hline Age $60+$ & $\begin{array}{l}0.009 \\
(0.103)\end{array}$ & $\begin{array}{l}0.010 \\
(0.103)\end{array}$ \\
\hline
\end{tabular}


Table 5 (continued)

\begin{tabular}{lll}
\hline & $(2)$ & $(1)$ \\
& Vote3 & Vote3 \\
\hline Unemployed & $0.437 * * *$ & $0.438 * * *$ \\
& $(0.082)$ & $(0.082)$ \\
Political trust & $-0.132 * * *$ & $-0.132 * * *$ \\
& $(0.017)$ & $(0.017)$ \\
HHS & $0.748 * *$ & $0.748 * *$ \\
Gender gap unemployment & $(0.348)$ & $(0.347)$ \\
GDP pc (log) & 0.551 & 0.549 \\
& $(0.656)$ & $(0.656)$ \\
EQI & -0.112 & -0.112 \\
& $(0.082)$ & $(0.082)$ \\
Constant & -0.286 & -0.285 \\
Obs. & $(0.620)$ & $(0.620)$ \\
Psuedo R-squared & $1.228 * * *$ & $1.249 * * *$ \\
\hline
\end{tabular}

Multinomial logit estimates are logged odds with country-clustered standard errors are in parenthesis. Baseline group is loyalty $* * * p<0.01 ; * * p<0.05$

Table 6 Re-test of H2 with country-level moderating variables

\begin{tabular}{lllll}
\hline & $(3)$ & $(4)$ & $(2)$ & $(1)$ \\
& $\mathrm{H} 1$ & $\mathrm{H} 2$ & $\mathrm{H} 1$ & $\mathrm{H} 2$ (alternative) \\
\hline $\begin{array}{l}\text { S1: exit (0) versus voting (1) } \\
\text { Female }\end{array}$ & $-0.071^{* * *}$ & $-0.117^{*}$ & $-0.071^{* * *}$ & $-0.063^{* * *}$ \\
& $(0.019)$ & $(0.069)$ & $(0.019)$ & $(0.021)$ \\
Health exp. & -0.096 & -0.100 & -0.091 & -0.091 \\
& $(0.150)$ & $(0.148)$ & $(0.145)$ & $(0.145)$ \\
Female* health & & 0.007 & & \\
University & & $(0.010)$ & & $0.434^{* * *}$ \\
Age 30-44 & $0.430 * * *$ & $0.430^{* * *}$ & $0.434 * * *$ & $(0.053)$ \\
& $(0.050)$ & $(0.050)$ & $(0.053)$ & -0.060 \\
Age 45-59 & -0.060 & -0.060 & -0.060 & $(0.039)$ \\
& $(0.039)$ & $(0.039)$ & $(0.039)$ & $-0.068^{*}$ \\
\end{tabular}


Table 6 (continued)

\begin{tabular}{|c|c|c|c|c|}
\hline \multirow{3}{*}{ Age 60+ } & \multirow{2}{*}{$\begin{array}{l}\text { (3) } \\
\mathrm{H} 1\end{array}$} & \multirow{2}{*}{$\begin{array}{l}(4) \\
\mathrm{H} 2\end{array}$} & \multirow{2}{*}{$\begin{array}{l}(2) \\
\mathrm{H} 1\end{array}$} & \multirow{2}{*}{$\begin{array}{l}\text { (1) } \\
\mathrm{H} 2 \text { (alternative) }\end{array}$} \\
\hline & & & & \\
\hline & $-0.260 * * *$ & $-0.260 * * *$ & $-0.258 * * *$ & $-0.258 * * *$ \\
\hline & $(0.056)$ & $(0.056)$ & $(0.057)$ & $(0.057)$ \\
\hline \multirow[t]{2}{*}{ Unemployed } & $-0.414 * * *$ & $-0.414 * * *$ & $-0.414 * * *$ & $-0.414 * * *$ \\
\hline & $(0.078)$ & $(0.078)$ & $(0.079)$ & $(0.079)$ \\
\hline \multirow[t]{2}{*}{ Political trust } & $0.106^{* * *}$ & $0.106^{* * * *}$ & $0.107 * * *$ & $0.107 * * *$ \\
\hline & $(0.015)$ & $(0.015)$ & $(0.015)$ & $(0.015)$ \\
\hline \multirow[t]{2}{*}{ GDP pc (log) } & 0.417 & 0.417 & 0.403 & 0.403 \\
\hline & $(0.761)$ & $(0.762)$ & $(0.746)$ & $(0.746)$ \\
\hline Gender wage gap & 0.023 & 0.023 & 0.023 & 0.023 \\
\hline \multirow[t]{2}{*}{ DM } & & & 0.002 & 0.002 \\
\hline & & & $(0.003)$ & $(0.002)$ \\
\hline \multirow[t]{2}{*}{ Female *DM } & & & & -0.001 \\
\hline & & & & $(0.000)$ \\
\hline \multirow[t]{2}{*}{ Constant } & -3.928 & -3.905 & -3.838 & -3.841 \\
\hline & $(7.205)$ & (7.217) & (7.103) & $(7.102)$ \\
\hline \multicolumn{5}{|c|}{ S2: loyalty (0) versus voice (1) } \\
\hline \multirow[t]{2}{*}{ Female } & $0.198 * * *$ & -0.068 & $0.198 * * *$ & $0.197 * * *$ \\
\hline & $(0.029)$ & $(0.125)$ & $(0.029)$ & $(0.030)$ \\
\hline \multirow[t]{2}{*}{ Health exp. } & $-0.221 * * *$ & $-0.239 * * *$ & $-0.217 * * *$ & $-0.217 * * *$ \\
\hline & $(0.084)$ & $(0.085)$ & $(0.081)$ & $(0.081)$ \\
\hline \multirow[t]{2}{*}{ Female * health } & & $0.037 * *$ & & \\
\hline & & $(0.018)$ & & \\
\hline \multirow[t]{2}{*}{ University } & 0.075 & 0.076 & 0.078 & 0.078 \\
\hline & $(0.067)$ & $(0.068)$ & $(0.069)$ & $(0.069)$ \\
\hline \multirow[t]{2}{*}{ Age $30-44$} & -0.023 & -0.024 & -0.023 & -0.023 \\
\hline & $(0.051)$ & $(0.051)$ & $(0.051)$ & $(0.051)$ \\
\hline \multirow[t]{2}{*}{ Age 45-59 } & -0.144 & -0.145 & -0.144 & -0.144 \\
\hline & $(0.094)$ & $(0.094)$ & $(0.094)$ & $(0.094)$ \\
\hline \multirow[t]{2}{*}{ Age $60+$} & $-0.351 * * *$ & $-0.351 * * *$ & $-0.350 * * *$ & $-0.350 * * *$ \\
\hline & (0.099) & $(0.099)$ & $(0.099)$ & $(0.099)$ \\
\hline \multirow[t]{2}{*}{ Unemployed } & 0.058 & 0.059 & 0.058 & 0.058 \\
\hline & $(0.097)$ & $(0.097)$ & $(0.097)$ & $(0.097)$ \\
\hline \multirow[t]{2}{*}{ Political trust } & $-0.056^{* *}$ & $-0.056^{* *}$ & $-0.055^{* *}$ & $-0.055^{* *}$ \\
\hline & $(0.026)$ & $(0.026)$ & $(0.026)$ & $(0.026)$ \\
\hline \multirow[t]{2}{*}{ GDP pc (log) } & $1.493 *$ & $1.490^{*}$ & $1.488^{*}$ & $1.488^{*}$ \\
\hline & $(0.778)$ & $(0.777)$ & $(0.768)$ & $(0.768)$ \\
\hline \multirow[t]{2}{*}{ Gender wage gap } & -0.002 & -0.002 & -0.003 & -0.003 \\
\hline & $(0.021)$ & $(0.021)$ & $(0.021)$ & $(0.021)$ \\
\hline \multirow[t]{2}{*}{ DM } & & & 0.001 & 0.001 \\
\hline & & & $(0.002)$ & $(0.003)$ \\
\hline \multirow[t]{2}{*}{ Female*DM } & & & & 0.000 \\
\hline & & & & $(0.000)$ \\
\hline
\end{tabular}


Table 6 (continued)

\begin{tabular}{lllll}
\hline & $(3)$ & $(4)$ & $(2)$ & $(1)$ \\
& H1 & H2 & H1 & H2 (alternative) \\
\hline Constant & -12.492 & -12.332 & $-12.467^{*}$ & $-12.466^{*}$ \\
Obs. & $(7.637)$ & $(7.609)$ & $(7.565)$ & $(7.565)$ \\
& 75,448 & 75,448 & 75,448 & 75,448 \\
\hline
\end{tabular}

Standard errors are in parenthesis

Logged odds from sequential logit estimation and country-clustered standard errors in parentheses. Models include all individual and contextual level covariates as model 3, Table 2, yet the contextual variables are measured at the country level. Estimates account for survey sample and design weights. Models 1 and 2 replicate Table 2 with country level variables, while 3 and 4 add district magnitude and test whether the gender gap in corruption voting is contingent on the level of proportionality in the system (model 4)

$* * * p<0.01 ; * * p<0.05 ; * p<0.1$

\section{References}

Aidt, T. S., \& Dallal, B. (2008). Female voting power: the contribution of women's suffrage to the growth of social spending in Western Europe (1869-1960). Public Choice, 134(3-4), 391-417.

Alexander, A. C. (2018). Micro-perspectives on the gender-corruption link. In I. Kubbe \& A. Engelbert (Eds.), Corruption and norms: Why informal rules matter (pp. 53-68). London: Palgrave Macmillan.

Alexander, A. C., \& Bågenholm, A. (2018). Does gender matter? Female politicians' engagement in anticorruption efforts. In H. Stensöta \& L. Wängnerud (Eds.), Gender and corruption (pp. 171-189). London: Palgrave Macmillan.

Bågenholm, A. (2013). Throwing the rascals out? The electoral effects of corruption allegations and corruption scandals in Europe 1981-2011. Crime, Law and Social Change, 60(5), 595-609.

Barberá, P., et al. (2012). The electoral consequences of political scandals in Spain. Paper presented at the XXII IPSA world congress of political science, Madrid, July 8-12.

Bauhr, M., \& Charron, N. (2018). Insider or outsider? Grand corruption and electoral accountability. Comparative Political Studies, 51(4), 415-446.

Buis, M. (2011). The consequences of unobserved heterogeneity in a sequential logit model. Research in Social Stratification and Mobility, 29(3), 247-262.

Casey, P. C. (2014). Voting for corruption: how poverty and inequality undermine democratic accountability in Latin America. All theses and dissertations (ETDs). 1226. Retrieved February 25, 2019, from http://openscholarship.wustl.edu/etd/1226.

Chang, E., et al. (2010). Legislative malfeasance and political accountability. World Politics, 62(2), $177-220$.

Charron, N. (2011). Party systems, electoral systems and constraints on corruption. Electoral Studies, 30(4), 595-606.

Charron, N., \& Bågenholm, A. (2016). Ideology, party systems and corruption voting in European democracies. Electoral Studies, 41, 35-49.

Charron, N., et al. (2015). Mapping the regional divide in Europe: A measure for assessing quality of government in 206 European regions. Social Indicators Research, 122(2), 315-346.

Charron, N., et al. (2019). Measuring quality of government in EU regions across space and time. Papers in Regional Science. https://doi.org/10.1111/pirs.12437.

Chaudhuri, A. (2012). Chapter 2 Gender and corruption: A survey of the experimental evidence. In D. Serra \& L. Wantchekon (Eds.), New advances in experimental research on corruption (pp. 13-49). Bingley: Emerald Group Publishing Limited.

Choi, E., \& Woo, J. (2010). Political corruption, economic performance, and electoral outcomes: A crossnational analysis. Contemporary Politics, 16(3), 249-262.

Chong, A., et al. (2014). Does corruption information inspire the fight or quash the hope? A field experiment in Mexico on voter turnout, choice, and party identification. The Journal of Politics, 77(1), 55-71.

Clark, W. R., et al. (2017). The British Academy Brian Barry prize essay: An exit, voice and loyalty model of politics. British Journal of Political Science, 47(4), 719-748.

Costas-Pérez, E. (2013). The effects of political corruption on turnout: Mobilization or disaffection. Barcelona: Universitat de Barcelona \& Institut d'Economia de Barcelona (IEB). 
Costas-Pérez, E., et al. (2012). Corruption scandals, voter information, and accountability. European Journal of Political Economy, 28(4), 469-484.

Cumming, D., Leung, T. Y., \& Rui, O. (2015). Gender diversity and securities fraud. Academy of Management Journal, 58(5), 1572-1593.

D’Attoma, J., Volintiru, C., \& Steinmo, S. (2017). Willing to share? Tax compliance and gender in Europe and America. Research \& Politics, 4(2), 2053168017707151.

Dahlberg, S., \& Solevid, M. (2016). Does corruption suppress voter turnout? Journal of Elections, Public Opinion and Parties, 26(4), 489-510.

de Sousa, L., \& Moriconi, M. (2013). Why voters do not throw the rascals out?-A conceptual framework for analyzing electoral punishment of corruption. Crime, Law and Social Change, 60, 471-502.

De Vries, C. E., \& Solaz, H. (2017). The electoral consequences of corruption. Annual Review of Political Science, 20, 391-408.

Dollar, D., et al. (2001). Are women really the fairer sex? Corruption and women in government. Journal of Economic Behaviour \& Organization, 46, 423-429.

Eagly, A. H., Wood, W., \& Diekman, A. B. (2000). Social role theory of sex differences and similarities: A current appraisal. In T. Eckes \& H. M. Trautner (Eds.), The developmental social psychology of gender. Mahwah: Erlbaum.

Eggers, A. C., et al. (2017). Corruption, accountability, and gender: Do female politicians face higher standards in public life? Journal of Politics, 80(1), 321-326.

Esarey, J., \& Chirillo, G. (2013). 'Fairer sex' or purity myth? Corruption, gender, and institutional context. Politics and Gender, 9, 361-389.

Esarey, J., \& Schwindt- Bayer, L. (2017). Women's representation, accountability, and corruption in democracies. British Journal of Political Science, 48(3), 659-690.

Eurobarometer 324. (2009). The attitudes of Europeans towards corruption. Retrieved February 25, 2019, from http://ec.europa.eu/public_opinion/archives/ebs/ebs_325_en.pdf.

Eurobarometer 374. (2012). Corruption. Retrieved February 25, 2019, from http://ec.europa.eu/public_opini on/archives/ebs/ebs_374_en.pdf.

Eurobarometer 470. (2017). Corruption. Retrieved February 25, 2019, from http://ec.europa.eu/commfronto ffice/publicopinion/index.cfm/Survey/index\#p=1\&instruments=SPECIAL.

Fernández-Vásquez, P., et al. (2016). Rooting out corruption or rooting for corruption? The heterogeneous electoral consequences of scandals. Political Science Research and Methods, 4(2), 379-397.

Fišar, M., Kubák, M., Špalek, J., \& Tremewan, J. (2016). Gender differences in beliefs and actions in a framed corruption experiment. Journal of Behavioral and Experimental Economics, 63, 69-82.

Gupta, M. S., \& Tiongson, E. (2000). Corruption and the provision of health care and education services (No. 0-116). Washington, DC: International Monetary Fund.

Hirschman, A. O. (1970). Exit, voice, and loyalty: Responses to decline in firms, organizations, and states (Vol. 25). Cambridge: Harvard University Press.

Iversen, T., \& Rosenbluth, F. (2006). The political economy of gender: Explaining cross-national variation in the gender division of labor and the gender voting gap. American Journal of Political Science, 50(1), 1-19.

Jha, C. K., \& Sarangi, S. (2018). Women and corruption: What positions must they hold to make a difference? Journal of Economic Behavior \& Organization, 151, 219-233.

Konstantinidis, I., \& Xezonakis, G. (2013). Sources of tolerance towards corrupted politicians in Greece: The role of trade-offs and individual benefits. Crime, Law and Social Change, 60(5), 549-563.

Kumlin, S., \& Rothstein, B. (2005). Making and breaking social capital: The impact of welfare-state institutions. Comparative Political Studies, 38(4), 339-365.

Kunikova, J., \& Rose-Ackerman, S. (2005). Electoral rules and constitutional structures as constraints on corruption. British Journal of Political Science, 35(4), 573-606.

Lott, J. R., Jr., \& Kenny, L. W. (1999). Did women's suffrage change the size and scope of government? Journal of Political Economy, 107(6), 1163-1198.

Manzetti, L., \& Wilson, C. J. (2007). Why do corrupt governments maintain public support? Comparative Political Studies, 40(8), 949-970.

Persson, A., et al. (2013). Why anticorruption reforms fail-Systemic corruption as a collective action problem. Governance, 26(3), 449-471.

Persson, T., et al. (2003). Electoral rules and corruption. Journal of the European Economic Association, 1(4), 958-989.

Reed, S. (1996). Political corruption in Japan. International Social Science Journal, 48(3), 395-405.

Rosenbaum, S. M., Billinger, S., \& Stieglitz, N. (2014). Let's be honest: A review of experimental evidence of honesty and truth-telling. Journal of Economic Psychology, 45, 181-196. 
Rothstein, B. (2001). Social capital in the social democratic welfare state. Politics \& Society, 29(2), 207-241.

Rothstein, B., \& Uslaner, E. M. (2005). All for all: Equality, corruption, and social trust. World Politics, $58(1), 41-72$.

Stegmueller, D. (2013). How many countries for multilevel modeling? A comparison of frequentist and Bayesian approaches. American Journal of Political Science, 57(3), 748-761.

Stensöta, H., et al. (2015). Why women in encompassing welfare states punish corrupt political parties. In C. Dahlström \& L. Wängnerud (Eds.), Elites, institutions and the quality of government (pp. 245-262). London: Palgrave Macmillan.

Sundström, A., \& Stockemer, D. (2015). Regional variation in voter turnout in Europe: The impact of corruption perceptions. Electoral Studies, 40, 158-169.

Sundström, A., \& Wängnerud, L. (2014). Corruption as an obstacle to women's political representation: Evidence from local councils in 18 European countries. Party Politics, 22(3), 354-369.

Swamy, A., et al. (2001). Gender and corruption. Journal of Development Economics, 64(1), 25-55.

Tavits, M. (2007). Clarity of responsibility and corruption. American Journal of Political Science, 51(1), 218-229.

Torlger, B., \& Valev, N. T. (2010). Gender and public attitudes toward corruption and tax evasion. Contemporary Economic Policy, 28(4), 554-568.

Vijayalakshmi, V. (2008). Rent-seeking and gender in local governance. Journal of Development Studies, 44(9), 1262-1288.

Winters, M. S., \& Weitz-Shapiro, R. (2013). Lacking information or condoning corruption: When do voters support corrupt politicians? Comparative Politics, 45(4), 418-436.

World Bank. (2001). Engendering development: Through gender equality in rights, resources and voice. A World Bank policy research report. Oxford: Oxford University Press.

Zechmeister, E. J., \& Zizumbo-Colunga, D. (2013). The varying political toll of concerns about corruption in good versus bad economic times. Comparative Political Studies, 46(10), 1190-1218.

Publisher's Note Springer Nature remains neutral with regard to jurisdictional claims in published maps and institutional affiliations. 